\title{
A Helicobacter pylori-fertózés első vonalbeli megszüntetésére alkalmazott hagyományos hármas és egy új, bizmuttartalmú négyes kezelés összehasonlítása
}

\author{
Varga Máté dr. ${ }^{1}$ - Drácz Lajos dr. ${ }^{2}$ - Kolbenheyer Erik dr. ${ }^{3}$ \\ Varga Ferenc dr. ${ }^{4}$. Patai Árpád V. dr. ${ }^{5,6}$ \\ Solymosi Norbert dr. ${ }^{7}$. Patai Árpád dr. ${ }^{1,5}$ \\ ${ }^{1}$ Markusovszky Egyetemi Oktatókórház, Gasztroenterológiai és Belgyógyászati Osztály, Szombathely \\ ${ }^{2}$ Szent László Kórház, Gasztroenterológiai Szakrendelés, Sárvár \\ ${ }^{3}$ MÁV Rendelőintézet, Gasztroenterológiai Szakrendelés, Szombathely \\ ${ }^{4}$ Dr. Batthyány-Strattmann László Kórház-Rendelőintézet, Gasztroenterológiai Szakrendelés, Körmend \\ ${ }^{5}$ Vitalitas Egészségközpont, Szombathely \\ ${ }^{6}$ Semmelweis Egyetem, Általános Orvostudományi Kar, II. Belgyógyászati Klinika, Budapest \\ 7Állatorvostudományi Egyetem, Bioinformatikai Központ, Budapest
}

Bevezetés és célkitüzés: Mivel a hagyományos, első vonalbeli Helicobacter pylori (H. p.)-eradicatiós kezelés hatékonysága hazánkban $75 \%$ alá csökkent, új protokoll kidolgozása szükséges.

Módszer: Föltételezve, hogy a hagyományos kezelés (14 napos kettős standard dózisú protonpumpagátló [PPI], $2 \times$ $1000 \mathrm{mg} /$ die amoxicillin, $2 \times 500 \mathrm{mg}$ klaritromicin [PAC]) sikerességi aránya 75\%, és az új protokoll (10 napos $4 \times$ $120 \mathrm{mg}$ bizmut-dicitrát, kétszeres standard dózisú PPI, $4 \times 500 \mathrm{mg}$ tetraciklin, $2 \times 500 \mathrm{mg} /$ die tinidazol [BQT]) eredményessége 95\%, karonként 109 beteg bevonásával számoltunk. A páciensek beválasztására 5 Vas megyei endoszkópos laboratóriumban elvégzett felsô tápcsatornai endoszkópia után került sor. A csoportok heterogenitását, a kezelés sikerességét és a mellékhatásokat Fisher-féle egzakt próbával értékeltük; a p <0,05 értéket szignifikánsnak tekintettük.

Eredmények: A BQT-kezelésű csoportba 110 beteget vontunk be, míg a PAC-kezelésűbe 109 beteget. A két csoport között a kor, a nem és a kiirtás javallata alapján nem volt különbség. A H. p.-fertőzés felszámolásának sikeressége a BQT esetén 103/110 (93,6\%), a PAC esetén pedig 81/109 (74,3\%) volt (p<0,001). Az esélyhányados a BQT esetén a PAC-kezeléssel összehasonlítva 5,05 volt (95\%-os megbízhatósági tartomány 2,02-14,42; p<0,001). A BQT esetén mellékhatás a betegek 34,5\%-ában jelentkezett.

Következtetés: A H. p. kiirtására javasolt a 10 napos bizmuttartalmú, kétszeres standard dózisú PPI-t, $4 \times 500$ mg/die tetraciklint és $2 \times 500 \mathrm{mg}$ /die tinidazolt tartalmazó kezelés, mivel ez hatékony, és elfogadható mellékhatásprofillal jár.

Orv Hetil. 2019; 160(34): 1340-1345.

Kulcsszavak: Helicobacter pylori, bizmut, tinidazol, tetraciklin, antibiotikumrezisztencia, eradicatio

Comparison of the traditional triple and a new bismuth-containing quadruple therapy in the first-line eradication of Helicobacter pylori

Introduction and aim: As the efficacy of the first-line traditional treatment used to eradicate Helicobacter pylori (H. p.) decreased below $75 \%$ in Hungary, a new protocol had to be created.

Method: Supposing the success rate of the traditional therapy (14-day double dose of proton pump inhibitor [PPI], $1000 \mathrm{mg}$ amoxicillin b.i.d., $500 \mathrm{mg}$ clarithromycin b.i.d. [PAC]) to be $75 \%$ and the efficacy of the new protocol 
(10-day $120 \mathrm{mg}$ bismuth dicitrate q.i.d., double dose PPI b.i.d., $500 \mathrm{mg}$ tetracycline q.i.d. and $500 \mathrm{mg}$ tinidazole b.i.d. [BQT]) to be $90 \%$, we calculated 109 patients on each arm. Patients were recruited after upper gastrointestinal endoscopy from 5 endoscopic units in Vas county. The heterogeneity of groups, success rate and side effects of both therapies were evaluated by Fisher exact test; $\mathrm{p}<0.05$ was considered significant.

Results: 110 patients were included in the BQT and 109 patients in the PAC group. There was no heterogeneity between the two groups in age, gender and indication of eradication. H. p. eradication was successful in $103 / 110$ $(93.6 \%)$ in the BQT and $81 / 109(74.3 \%)$ in the PAC group $(\mathrm{p}<0.001)$. The odds ratio in the BQT group for successful eradication was 5.05 (95\% confidence interval: $2.02-14.42)$ as compared to the PAC group ( $\mathrm{p}<0.001)$. The side effects of the two groups were similar, in the BQT group the frequency was $34.5 \%$.

Conclusion: 10 day-long BQT containing double dose PPI with $120 \mathrm{mg}$ bismuth dicitrate q.i.d., $500 \mathrm{mg}$ tetracycline q.i.d. and $500 \mathrm{mg}$ tinidazole b.i.d. is recommended as the first-line treatment for the eradication of $H$. $p$. because of its high efficacy and tolerable side effects.

Keywords: Helicobacter pylori, bismuth, tetracycline, tinidazole, antibiotic resistance, eradication

Varga M, Drácz L, Kolbenheyer E, Varga F, Patai ÁV, Solymosi N, Patai Á. [Comparison of the traditional triple and a new bismuth-containing quadruple therapy in the first-line eradication of Helicobacter pylori]. Orv Hetil. 2019; 160(34): 1340-1345.

(Beérkezett: 2019. március 11.; elfogadva: 2019. április 9.)

\section{Rövidítések}

BQT = (bismuth quadruple therapy) bizmut négyes terápia; DNS $=$ dezoxiribonukleinsav; FDA $=$ (U.S. Food and Drug Administration) az Amerikai Egyesült Államok Élelmiszer-biztonsági és Gyógyszerészeti Hivatala; H. p. = Helicobacter pylori; MALT $=($ mucosa-associated lymphoid tissue $)$ mucosaasszociált lymphoma; NSAID $=$ (non-steroidal anti-inflammatory drug $)$ nemszteroid gyulladásgátló; $\mathrm{PAC}=($ protonpump inhibitor, amoxicillin, clarithromycin) protonpumpagátló, amoxicillin, klaritromicin; PPI = (proton-pump inhibitor $)$ protonpumpagátló

A Helicobacter pylori (H. p.) az egyik leggyakoribb, emberről emberre terjedő patogén baktérium. Kiirtásának javallata folyamatosan bóvült a $H$. $p$. (újra)fölfedezése óta eltelt 35 évben [1-6]. Kezdetben az ulcus pepticum, illetve a fekélyvérzés recidívájának megelőzése volt az eradicatio célja $[7,8]$. A későbbiekben a $H$. p.-pozitív gastritis chronica talaján kialakuló mucosaasszociált lymphoma (MALT) és a gyomorrák miatt végzett gyomorreszekció utáni állapot is bekerült a javallatok közé, mivel egyre több adat utalt a $H$. p.-nak a malignus folyamatok kialakításában játszott szerepére $[4-6,9,10]$. Azokban a gastrooesophagealis reflux betegségben szenvedőkben, akikben $H$. p.-pozitivitásra derül fény, a $H$. $p$. felszámolása szintén előnyökkel jár $[4-6,11]$. A funkcionális dyspepsiában szenvedők $H$. p.-pozitivitásának szerepe kezdetben sok vitát váltott ki, ma a $H$. $p$. kiirtásának igénye már széles körben elfogadott [4-6, 12-14]. A véralvadást és a thrombocytaaggregatiót gátló tartós gyógyszeres kezelés, továbbá a tartós nemszteroid gyulladáscsökkentő terápia megkezdése előtt a gyakori és föleg a 65 év fölöttiekben magas mortalitással járó felső tápcsatornai vérzések megelőzésére szintén megerősítették a $H$. p.-kiirtás javallatát $[4,15]$. A mással nem magyarázott vashiányos anaemiában, továbbá az idiopathiás thrombocytopeniás purpurában szenvedőkben a $H$. $p$. felszámolását hasonlóképpen javasolják $[4,5]$. Az utóbbi évek adatai alapján a $H$. p.-asszociált gastritis chronica praecancerosus állapotnak minősül, így a gyomornyálkahártya-gyulladás egyetlen kezelési lehetőségeként, különösen a 60 év alatti korosztályban, a $H$. p.-fertőzés megszüntetése a gyomorrák-megelőzés részévé vált $[2,16]$.

Sajnos a $H$. p.-fertőzés felszámolási javallatának kiszélesedése egyre emelkedő antibiotikumrezisztenciával párosult. Ennek a világszerte tapasztalt jelenségnek [17, 18] a következtében a hagyományos első vonalbeli eradicatiós terápiák hatékonysága $80 \%$ alá csökkent, ami elfogadhatatlanul alacsony [19]. Hazai szerzők több közleményben hívták föl a figyelmet arra, hogy az első vonalbeli kezelés hatékonysága Magyarországon is kritikusan alacsony, 75\% alatti, aminek az oka lehet, hogy a H. p. kiirtására gyakorta alkalmazott antibiotikumokkal szembeni rezisztencia magas $[17,20-23]$. Mindezek alapján javasolták új első vonalbeli kezelési protokoll bevezetését az eradicatio sikerességének növelésére [21].

Tanulmányunkban a hagyományos, 2 héten át alkalmazott napi kétszeres standard dózisú protonpumpagátlót (PPI), $2 \times 1000 \mathrm{mg} /$ die amoxicillint és $2 \times 500 \mathrm{mg} /$ die klaritromicint tartalmazó kezelést (PAC) hasonlítottuk össze egy új, 10 napig tartó négyes, napi kétszeres standard dózisú PPI-t, $4 \times 120 \mathrm{mg} /$ die bizmut-dicitrátot, $4 \times 500 \mathrm{mg} /$ die tetraciklint és $2 \times 500 \mathrm{mg} /$ die tini- $^{-}$ dazolt tartalmazó kezeléssel (BQT).

\section{Módszer}

A szükséges betegszámot 5\%-os első- és 20\%-os másodfajú hibával, Fisher-féle egzakt próba alapú szimulációval becsültük. Föltételeztük, hogy a hagyományos PAC sikerességi aránya $75 \%$, az új BQT sikerességi aránya $90 \%$. Így a karonkénti betegszámot 109-nek terveztük. Nem 
vontunk be olyan beteget a vizsgálatba, akinek bármely szóba jövő gyógyszerrel szemben ismert allergiája volt. 5 Vas megyei endoszkópos laboratórium (Markusovszky Egyetemi Oktatókórház, Gasztroenterológiai és Belgyógyászati Osztály, Szombathely; Szent László Kórház, Gasztroenterológiai Szakrendelés, Sárvár; MÁV Rendelőintézet, Gasztroenterológiai Szakrendelés, Szombathely; Dr. Batthyány-Strattmann László Kórház-Rendelőintézet, Gasztroenterológiai Szakrendelés, Körmend; valamint Vitalitas Egészségközpont, Szombathely) felső tápcsatornai endoszkópián átesett 109, PAC-terápiát alkalmazó betegét a tanulmány megkezdése után indított BQT-kezelésben részesülő betegekkel hasonlítottuk öszsze. A Helicobacter pylori-pozitivitást az antrum és a corpus ventriculiból vett szövetmintákon gyors ureázteszttel igazoltuk. Betegeink $H$. p.-statusát $\mathrm{C}^{13}$-urea-kilégzési gyorsteszttel ellenőriztük a terápia befejezése után legalább 6 héttel; a PPI-t a $\mathrm{C}^{13}$-urea-kilégzési gyorsteszt elvégzése előtt 2 héttel állítottuk le. Betegeinknek probiotikum alkalmazását nem javasoltuk [4]. A mellékhatásokat kérdőívvel mértük föl. A tanulmányt a Helsinkiben jóváhagyott és többször módosított megállapodások szerint, a „helyes klinikai gyakorlat” irányelveinek megfelelően, a Szombathelyi Regionális és Helyi Etikai Bizottság engedélyével (11/2018) végeztük el.

A két csoport heterogenitását, az eradicatio sikerességének esélyhányadosát, az eredményesség és a mellékhatások különbözőségét Fisher-féle egzakt próbával teszteltük, a szignifikancia szintjét $\mathrm{p}<0,05$-ban határoztuk meg. \begin{tabular}{l|l} 
1. táblázat & $\begin{array}{l}\text { A két kezelt csoport összehasonlítása életkor, nemi megoszlás és } \\
\text { javallat alapján }\end{array}$
\end{tabular}

\begin{tabular}{lccc}
\hline & $\begin{array}{c}\text { PAC } \\
(\mathrm{n}=109)\end{array}$ & $\begin{array}{c}\text { BQT } \\
(\mathrm{n}=110)\end{array}$ & $\mathrm{p}$ \\
\hline Életkor (év \pm szórás) & $51,5 \pm 12,9$ & $50,9 \pm 12,0$ & 0,67 \\
Nem (nő/férfi) & $56 / 53$ & $58 / 52$ & 0,89 \\
$\begin{array}{l}\text { A H. p. kiirtásának javallata } \\
\text { Gastritis chronica }\end{array}$ & 39 & 31 & 0,25 \\
Ulcus pepticum & 18 & 19 & 1 \\
$\begin{array}{l}\text { Hosszas NSAID-kezelés elött } \\
\text { Hosszas thrombocytaaggregatio- } \\
\text { gátló kezelés elött }\end{array}$ & 16 & 22 & 0,37 \\
MALT & 24 & 30 & 0,43 \\
Gyomorcarcinomás beteg rokona & 6 & & 0,62 \\
$\begin{array}{l}\text { Gyomorcarcinoma miatti } \\
\text { gyomormútétet követóen }\end{array}$ & 4 & 4 & 0,54 \\
\hline
\end{tabular}

BQT $=10$ napos kétszeres standard dózisú protonpumpagátlót, $4 \times$ $120 \mathrm{mg} /$ die bizmut-dicitrátot, $4 \times 500 \mathrm{mg} /$ die tetraciklint, $2 \times 500$ mg/die tinidazolt tartalmazó kezelés; H. p. = Helicobacter pylori; MALT = mucosaasszociált lymphoma; NSAID = nemszteroid gyulladásgátló; PAC $=14$ napos kétszeres standard dózisú protonpumpagátlót, $2 \times 1000 \mathrm{mg} /$ die amoxicillint és $2 \times 500 \mathrm{mg} /$ die klaritromicint tartalmazó kezelés

\section{Eredmények}

Összesen 110 beteg részesült BQT-ban, 109 beteg pedig PAC-terápián esett át. A két betegcsoport a korösszetétel, a nemi megoszlás, valamint a $H$. p.-fertôzés felszámolását indokoló kórképek vonatkozásában heterogenitást nem mutatott (1. táblázat). A H. p.-fertőzés felszámolása eredményes volt BQT-ban 103 betegben, ami 93,6\%-os sikerességi rátát jelent; PAC esetén csak 81 beteg vált $H$. p.-mentessé, ez 74,3\%-os eredményességet tükröz. A $H$. p.-kiirtás sikerességi aránya a két csoport között szignifikánsan különbözött, $\mathrm{p}<0,0001$ (2. táblá$z a t$ ). A két csoportban az egyes PPI-k hasonló arányban szerepeltek, a PPI-választás a $H$. p.-fertőzés-felszámolás sikerességének mértékét nem befolyásolta.

A BQT-csoportban a gyógyulás esélye 5 -ször nagyobb (esélyhányados: 5,05, 95\%-os megbízhatósági tartomány: 2,02-14,42, p<0,001). Kérdő́ives módszerünkkel

2. táblázat |A két kezelt csoportban a sikeresség összehasonlítása

\begin{tabular}{lccc}
\hline & PAC $(\mathrm{n}=109)$ & BQT $(\mathrm{n}=110)$ & $\mathrm{p}$ \\
\hline Sikeresség n $(\%)$ & $81(74,3 \%)$ & $103(93,6 \%)$ & $<0,0001$ \\
\hline
\end{tabular}

$\mathrm{BQT}=10$ napos kétszeres standard dózisú protonpumpagátlót, $4 \times$ $120 \mathrm{mg} /$ die bizmut-dicitrátot, $4 \times 500 \mathrm{mg} /$ die tetraciklint, $2 \times 500$ $\mathrm{mg} /$ die tinidazolt tartalmazó kezelés; PAC $=14$ napos kétszeres standard dózisú protonpumpagátlót, $2 \times 1000 \mathrm{mg} /$ die amoxicillint és $2 \times$ $500 \mathrm{mg} /$ die klaritromicint tartalmazó kezelés

3. táblázat $\mid$ A két kezelt csoportban észlelt mellékhatások összehasonlítás (egy-egy beteg akár több mellékhatást megjelölhetett)

\begin{tabular}{lccc}
\hline & $\begin{array}{c}\text { PAC } \\
(109 \text { beteg })\end{array}$ & $\begin{array}{c}\text { BQT } \\
(110 \text { beteg })\end{array}$ & $\mathrm{p}$ \\
\hline $\begin{array}{l}\text { A mellékhatást panaszoló } \\
\text { betegek száma }\end{array}$ & 40 & 38 & 0,78 \\
Az egyes mellékhatások száma & & & \\
Hányinger & 30 & 26 & 0,54 \\
Hányás & 5 & 3 & 0,5 \\
Hasi fájdalom & 14 & 12 & 0,68 \\
Hasmenés & 14 & 11 & 0,53 \\
Székrekedés & 3 & 4 & 1 \\
Puffadás & 12 & 9 & 0,5 \\
Fejfájás & 7 & 9 & 0,8 \\
Viszketés, kiütés & 6 & 5 & 0,77 \\
Gyengeség, szédülés & 8 & 6 & 0,59 \\
Fémes szájíz & 0 & 1 & 1 \\
Étvágytalanság & 14 & 11 & 0,53 \\
Külsó nemi szervek gyulladása & 1 & 0 & 0,5 \\
\hline & & &
\end{tabular}

BQT = 10 napos kétszeres standard dózisú protonpumpagátlót, $4 \times$ $120 \mathrm{mg} /$ die bizmut-dicitrátot, $4 \times 500 \mathrm{mg} /$ die tetraciklint, $2 \times 500$ $\mathrm{mg} /$ die tinidazolt tartalmazó kezelés; PAC $=14$ napos kétszeres standard dózisú protonpumpagátlót, $2 \times 1000 \mathrm{mg} /$ die amoxicillint és $2 \times$ $500 \mathrm{mg} /$ die klaritromicint tartalmazó kezelés 
számos mellékhatást tártunk fel (3. táblázat), a BQT mellett a betegek 34,5\%-a panaszolt mellékhatást. Mellékhatások miatt egy betegünk sem szakította meg a kezelést. A nagy számban rögzített mellékhatások gyakorisága a kétféle kezelési csoport között (PAC: 36,5\%, BQT: 34,5\%, p = 0,78) nem különbözött egymástól.

\section{Megbeszélés}

A 60000 éve velünk együtt élő $H$. p. [24] kiirtásának igénye alig több mint 3 évtizede jelent kihívást a kezelőorvosok számára. Az általunk is hagyományosan alkalmazott PAC-kezelés az 1997-ben közzétett európai irányelven nyugszik, amely a $H$. p. kiirtásában kiemeli a PPI-k szerepét a $\mathrm{H}_{2}$-receptor-blokkolókkal szemben, és ajánlja 7 napig három antibiotikum (klaritromicin, nitroimidazol [metronidazol vagy tinidazol], valamint amoxicillin) közül kettővel kiegészített alkalmazásukat [25]. Az összes $H$. p.-eradicatiós terápia közül egyedül a PACkezelés rendelkezik FDA-jóváhagyással [5]. Egyre szaporodó kudarcaink miatt az eradicatiós PAC-terápia hosszát ugyan 14 napra növeltük, a $H$. p.-felszámolás sikerességi aránya jelen tanulmányunk idejére 74,3\%-ra csökkent. Bár a $H$. p. antibiotikumrezisztencia-vizsgálatát megyénkben nem végeztük el, az alacsony $H$. p.-kiirtási eredményt a környezetünkben igazolt, egyre növekedő antibiotikumrezisztencia következményének tartjuk. A nagyszámú, hosszan tartó, kombinált, de 25,7\%-ban eredménytelen antibiotikus kezelés nemcsak fölösleges terhet jelent a páciensek számára, hanem tovább növeli a szervezetben élő többi baktérium amúgy is magas antibiotikumrezisztenciáját [26].

Mivel hazánk is azok közé az országok közé tartozik, ahol a $H$. p. klaritromicin- és metronidazolrezisztenciája meghaladja a 15\%-ot $[17,24,27]$, az európai ajánlásnak megfelelően olyan első vonalbeli négyes kezelést dolgoztunk ki, mely a PPI és a bizmut mellett két olyan antibiotikumot tartalmaz, amellyel szemben a $H$. $p$. nem rendelkezik magas rezisztenciaszinttel [6]. A kezelés időtartamát célszerü 10 napra rövidíteni, hiszen a 10 és a 14 napos kezelés között nem mutatkozott hatásosságban különbség, mindkét esetben 90\% fölötti a sikeresség $[6,17]$. Ugyanakkor hangsúlyozzák, hogy a 10 napos, bizmuttartalmú négyes kezelésrőll csekély számú tanulmány áll rendelkezésre $[6,28]$.

Új első vonalbeli kezelésünk alappillére a 10 napig alkalmazott, kétszeres standard dózisú PPI [6]. A PPI-nek a $H$. p. elleni közvetlen hatása csekély ugyan, de például omeprazolt adva amoxicillin és klaritromicin mellé akár 68\%-kal növelheti az eredményesség mértékét [29]. Ez a sikerességet növelő hatás különösen kifejezett, ha a gyomor-pH-t tartósan 6 fölé emelik [30]. A PPI-metabolizmusban döntő szerepet játszó CYP2C19-gén polimorfizmusa jelentősen módosíthatja a hatékonyságot, egy tanulmány adatai szerint a gyors metabolizálókban 16,8\%-kal alacsonyabb volt a kiirtás eredményessége [31]. Mindezek alapján a PPI-dózis emelése, így a leg- alább kétszeres standard dózis alkalmazása elónyös a $H$. p. felszámolására [32]. Föltehetően előrelépést jelenthet majd a CYP2C19-enzimtól független káliumkompetitív savgátlók (például vonoprazan) bevezetése, bár egyelőre Japánon kívüli tapasztalatok nem ismertek [32-34].

A bizmut első vonalbeli alkalmazása mellett szól, hogy a $H$. p.-ban nem alakul ki ellene rezisztencia, és nem növeli az emberi szervezetben található számos baktérium antibiotikumrezisztenciáját sem [6]. A bizmutsók közül azt kell választanunk, amelynek a fölszívódása minimális, hogy elkerüljük a nehézfémek esetén gyakran tapasztalt toxicitást. A bizmut-dicitrát a gyomorban oldhatatlan, kolloidális csapadékot képez, kevesebb, mint 0,2\%-a szívódik fel $[35,36]$. Hatásosságát jól tükrözi az a vizsgálat, amely szerint bizmut mellett a fél dózisban adott amoxicillin és klaritromicin ugyanolyan sikeresnek bizonyult a $H$. p. kiirtásában, mint a teljes dózis, ugyanakkor kevesebb mellékhatással járt, és gazdaságosabb is volt [37]. A bizmut kedvező hazai megítélését jelzi az a fölmérés, mely szerint a $H$. p. eradicatiójára a bizmutsót első vonalbeli kezelésként az orvosok kétharmada használja [38].

A H. p.-fertőzés első vonalbeli megszüntetésének legnagyobb dilemmája a két antibiotikum kiválasztása. Mivel a $H$. p. antibiotikumrezisztenciája levofloxacin esetén meghaladta a $25 \%$-ot, klaritromicin esetén a 30\%-ot, metronidazol esetén pedig a 40\%-ot [17], ezek kerülése kézenfekvőnek látszik. Az 5-imidazol-csoportba tartozó vegyületek mindegyike prodrug, fó hatásuk a célsejtbe való bejutást követően a nitrocsoport redukciója révén létrejött letális DNS-károsodás mindegyik tagjában azonos, mégis a farmakokinetika, a minimális letális koncentráció, az ezekból fakadó hatékonyság és a mellékhatásprofil jelentősen különbözik az eltérő oldalcsoportok miatt, így a metronidazol helyettesítésére a tinidazol jön szóba. Magyarországon a tinidazol használata az elmúlt években alacsonyabb volt a metronidazolénál, így okkal várható, hogy a H. p. tinidazolrezisztenciája jóval alacsonyabb, mint a metronidazol esetében. További előny, hogy a tinidazolt elegendő naponta kétszer és alacsonyabb dózisban alkalmazni, valamint mellékhatásprofilja lényegesen kedvezőbb a metronidazolénál [39-43]. A klaritromicin helyett egy szintén makrolid, a tetraciklin alkalmazása mellett azért döntöttünk, mert e baktericid, fehérjeszintézist gátló antibiotikum használata az elmúlt évtizedekben Magyarországon jelentősen visszaszorult, a $H$. p. tetraciklinrezisztenciája kifejezetten alacsony [ 40 , 44-45].

Vizsgálatunkba bevont betegeink $H$. p.-kiirtásának javallata megfelel a nemzetközi gyakorlatnak $[2,6]$, és a két vizsgált csoportban lényegesen nem tér el egymástól.

Eredményeink szerint az új összetételú, 10 napig alkalmazott BQT mellett ötször nagyobb a $H$. p. sikeres kiirtásának esélye, mint a hagyományos, 14 napos PACkezelés mellett: BQT mellett a felszámolás sikeressége elérte a 93,6\%-ot, és jelentősen meghaladta a PAC $74,3 \%$-os hatásosságát. Feltehetően a gyakran alkalma- 
zott metronidazol helyett a ritkábban fölírt tinidazol bevezetése miatt mind a hatásosság, mind a mellékhatásgyakoriság kedvezőbb, mint a bizmut-metronidazol-klaritromicin és PPI kombinációé, amely 21 tanulmány metaanalízise alapján 90\%-os kiirtási arány mellett 41\%os mellékhatás-gyakoriságot mutatott [46]. Az általunk bevezetett BQT-val elért $H$. p.-fertőzés-felszámolási eredményeink fölülmúlták a hasonló elvek alapján kialakított protokollok sikerességi arányát (45-50). A 10 napos BQT mellékhatásai $(34,5 \%)$ nem gyakoribbak, mint a korábbi 14 napos PAC-kezeléséi $(36,5 \%)$; tanulmányunkban egy beteg sem döntött a kezelés fölfüggesztése mellett. Előnye az általunk alkalmazott BQT-nak, hogy elegendő 10 napon át alkalmazni, ami mind a beteg-együttmúködés, mind a mellékhatások gyakorisága, mind gazdasági megfontolások alapján jelentős előnyt jelent a 14 napos protokollokkal szemben.

Tanulmányunk korlátait jelenti, hogy ugyanilyen terápiás protokollok összevetésére adatot nem találtunk az irodalomban. Nem vizsgáltuk betegeink számos paraméterét, így dohányzási szokásaikat, testtömegindexüket, a társbetegségek (például diabetes mellitus) jelenlétét és az ezek miatti gyógyszerelés hatását sem. Kétségtelen, hogy alacsony volt bevont betegeink száma. Bár vizsgálatunk erőssége, hogy öt központ betegeinek beválasztásával készült, és a hatáskülönbség igazolására az előzetesen kalkulált betegszám bevonásra került, tanulmányunk mégis Magyarország egyetlen megyéjének betegeire korlátozódik. Eredményeink megerősítésére nagyobb betegszámú, akár az ország határain kívülre is kiterjesztett, előre tervezett, véletlen beválasztásos vizsgálat elvégzését javasoljuk.

\section{Következtetés}

Az általunk bevezetett új, 10 napos BQT-kezelés a hagyományos, 14 napos PAC-kezeléssel szemben nemcsak ötször nagyobb esélyt biztosít a sikeres $H$. p.-kiirtásra, hanem elfogadható mellékhatásprofilja miatt széles körü használatra is alkalmas.

Anyagi támogatás: A közlemény megírása, illetve a kapcsolódó kutatómunka anyagi támogatásban nem részesült.

Szerzői munkamegosztás: V. M., P. Á. V., P. Á.: A tanulmány megtervezése, a betegek beválasztása, az adatok elemzése, a kézirat megírása, a kézirat szövegének végleges jóváhagyása. D. L., K. E., V. F.: A tanulmány megtervezése, a betegek beválasztása, az adatok elemzése, a kézirat szövegének végleges jóváhagyása. S. N.: A tanulmány megtervezése, az adatok statisztikai elemzése, a kézirat szövegének végleges jóváhagyása. A cikk végleges változatát valamennyi szerző elolvasta és jóváhagyta.

Érdekeltségek: A szerzőknek nincsenek érdekeltségeik.

\section{Irodalom}

[1] Marshall BJ, Warren JR. Unidentified curved bacilli in the stomach of patients with gastritis and peptic ulceration. Lancet 1984; 323: 1311-1315.

[2] Sugano K, Tack J, Kuipers EJ, et al. Kyoto global consensus re port on Helicobacter pylori gastritis. Gut 2015; 64: 1353-1367.

[3] Hunt RH, Camilleri M, Crowe SE, et al. The stomach in health and disease. Gut 2015; 64: 1650-1668.

[4] Fallone CA, Chiba N, van Zanten SV, et al. The Toronto consensus for the treatment of Helicobacter pylori infection in adults. Gastroenterology 2016; 151: 51-69.e14.

[5] Chey WD, Leontiadis GI, Howden CW, et al. ACG Clinical Guideline: Treatment of Helicobacter pylori infection. Am J Gastroenterol. 2017; 112: 212-239.

[6] Malfertheiner P, Megraud F, O'Morain CA, et al. Management of Helicobacter pylori infection - the Maastricht V/Florence Consensus Report. Gut 2017; 66: 6-30.

[7] Forbes GM, Glaser ME, Cullen DJ, et al. Duodenal ulcer treated with Helicobacter pylori eradication: seven-year follow-up. Lancet 1994; 343: 258-260.

[8] Malfertheiner P, Chan FK, McColl KE. Peptic ulcer disease. Lancet 2009; 374: 1449-1461.

[9] Patai Á. Pathomechanism and diagnosis of Helicobacter pylori infection. [A Helicobacter pylori infekció patomechanizmusa, kimutatása.] Orvosképzés 1997; 72: 370-374. [Hungarian]

[10] Witkowska M, Smolewski P. Helicobacter pylori infection, chronic inflammation, and genomic transformations in gastric MALT lymphoma. Mediators Inflamm. 2013; 2013: 523170.

[11] Patai Á, Jakab Zs, Rácz I, et al. The frequency of gastroesophageal reflux disease in patients with Helicobacter pylori positive duodenal ulcer in West Hungary. Z Gastroenterol. 2000; 38: A420.

[12] Malfertheiner P, Mossner J, Fischbach W, et al. Helicobacter pylori eradication is beneficial in the treatment of functional dyspepsia. Aliment Pharmacol Ther. 2003; 18: 615-625.

[13] Suzuki H, Nishizawa T, Hibi T. Can Helicobacter pylori-associated dyspepsia be categorized as functional dyspepsia? J Gastroenterol Hepatol. 2011; 26(Suppl 3): 42-45.

[14] Moayyedi P, Lacy BE, Andrews CN, et al. ACG and CAG Clinical Guideline: Management of dyspepsia. Am J Gastroenterol. 2017; 112: 988-1013

[15] Patai Á, Jakab Zs, Varga F, et al. Epidemiology of non-variceal upper gastrointestinal bleeding in Vas county. [A nem varix eredetû felső gastrointestinalis vérzés epidemiológiája Vas megyében.] Orv Hetil. 1998; 139: 2705-2712. [Hungarian]

[16] Pimentel-Nunes P, Libânio D, Marcos-Pinto R, et al. Management of epithelial precancerous conditions and lesions in the stomach (MAPS II): European Society of Gastrointestinal Endoscopy (ESGE), European Helicobacter and Microbiota Study Group (EHMSG), European Society of Pathology (ESP), and Sociedade Portuguesa de Endoscopia Digestiva (SPED) guideline update 2019. Endoscopy 2019; 51: 365-388.

[17] Megraud F, Coenen S, Versporten A, et al. Helicobacter pylori resistance to antibiotics in Europe and its relationship to antibiotic consumption. Gut 2013; 62: 34-42.

[18] Shao Y, Lu R, Yang Y, et al. Antibiotic resistance of Helicobacter pylori to 16 antibiotics in clinical patients. J Clin Lab Anal. 2018; 32: e22339.

[19] Thung I, Aramin H, Vavinskaya V, et al. Review article: The global emergence of Helicobacter pylori antibiotic resistance. Aliment Pharmacol Ther. 2016; 43: 514-5133.

[20] Prónai L, Tulassay Zs. Failure of Helicobacter pylori eradication - suggestions for further therapy. [A Helicobacter pylori eradikációjának sikertelensége: szempontok a további kezelés megítéléséhez.] Orv Hetil. 2003; 144: 1299-1302. [Hungarian] 
[21] Hagymási K, Tulassay Zs. The new aspects of the eradication of Helicobacter pylori and the importance of bacterial resistance. [A Helicobacter pylori eradikációjának legújabb szempontjai és a bakteriális rezisztencia jelentősége.] Orv Hetil. 2008; 149: 2029-2035. [Hungarian]

[22] Buzás GM, Lotz G, Kiss A. The Hungarian epidemiology of clarithromycin resistance in Helicobacter pylori infection. [A clarithromycinrezisztencia magyarországi epidemiológiája Helicobacter pylori-fertőzésben.] Orv Hetil. 2007; 148: 14611467. [Hungarian]

[23] Tiszai A, Sükösd F, Lénárt Z, et al. Primary resistance of Helicobacter pylori to clarithromycin in different regions of Hungary. Z Gastroenterol. 2010; 48: A619.

[24] Moodley Y, Linz B, Bond RP, et al. Age of the association between Helicobacter pylori and man. PLoS Pathog. 2012; 8: el002693.

[25] European Helicobacter Pylori Study Group. Current European concepts in the management of Helicobacter pylori infection. The Maastricht Consensus Report. Gut 1997; 41: 8-13.

[26] Patai Á. Diet and probiotics in treatment of inflammatory bowel disease. [Az étrend és a probiotikumok szerepe gyulladásos bélbetegség kezelésében.] Magy Belorv Arch. 2018; 71: 173-177. [Hungarian]

[27] Herszényi L, Barna Z, Varga ZsM, et al. High clarithromycin and levofloxacin resistance in Helicobacter Pylori strains isolated from patients in our high-volume academic endoscopic centre. Z Gastroenterol. 2012; 50: A30.

[28] Dore MP, Farina V, Cuccu M, et al. Twice-a-day bismuth-containing quadruple therapy for Helicobacter pylori eradication: a randomized trial of 10 and 14 days. Helicobacter 2011; 16: 295-300.

[29] Lind T, Mégraud F, Unge P, et al. The MACH2 study: role of omeprazole in eradication of Helicobacter pylori with 1-week triple therapies. Gastroenterology 1999; 116: 248-253.

[30] Sjöstedt S, Sagar M, Lindberg G, et al. Prolonged and profound acid inhibition is crucial in Helicobacter pylori treatment with a proton pump inhibitor combined with amoxicillin. Scand J Gastroenterol. 1998; 33: 39-43.

[31] Sahara S, Sugimoto M, Uotani T, et al. Twice-daily dosing of esomeprazole effectively inhibits acid secretion in CYP2C19 rapid metabolisers compared with twice-daily omeprazole, rabeprazole or lansoprazole. Aliment Pharmacol Ther. 2013; 38: 1129-1137.

[32] Mori H, Suzuki H. Role of acid suppression in acid-related diseases: proton pump inhibitor and potassium-competitive acid blocker. J Neurogastroenterol Motil. 2019; 25: 6-14.

[33] Kusunoki M, Yuki M, Ishitobi H, et al. Effect of age on effectiveness of vonoprazan in triple therapy for Helicobacter pylori eradication. Intern Med. 2019; 58: 1549-1555.

[34] Sugimoto M, Yamaoka Y. Role of vonoprazan in Helicobacter pylori eradication therapy in Japan. Front Pharmacol. 2019; 9: 1560.

[35] Thomas F, Bialek B, Hensel R. Medical use of bismuth: the two sides of the coin. J Clinic Toxicol. 2012; S3: 004.

[36] Li W, Jin L, Zhu N, et al. Structure of colloidal bismuth subcitrate (CBS) in dilute $\mathrm{HCl}$ : unique assembly of bismuth citrate dinuclear units $\left(\left[\mathrm{Bi}(\mathrm{cit})_{2} \mathrm{Bi}\right]^{2-}\right)$. J Am Chem Soc. 2003; 125: 12408-12409.

[37] Lu B, Wang J, Li J, et al. Half-dose clarithromycin-containing bismuth quadruple therapy is effective and economical in treat- ing Helicobacter pylori infection: a single-center, open-label, ran domized trial. Helicobacter 2019; 24: el2566.

[38] Márkus B, Matyasovszky M, Vörös K, et al. Diagnosis and treatment of Helicobacter pylori infection in Hungary. [A Helicobacter pylori fertőzés diagnosztikája és kezelése a hazai gyakorlatban.] Magy Belorv Arch. 2018; 71: 201-207. [Hungarian]

[39] Asadipour A, Edraki N, Nakhjiri M, et al. Anti-Helicobacter pylori activity and structure-activity relationship study of 2-alkylthio5-(nitroaryl)-1,3,4-thiadiazole derivatives. Iran J Pharm Res. 2013; 12: 281-287.

[40] Sobel JD, Nyirjesy P, Brown W. Tinidazole therapy for metronidazole-resistant vaginal trichomoniasis. Clin Infect Dis. 2001; 33: 1341-1346.

[41] Raja IM, Basavareddy A, Mukherjee D, et al. Randomized, double-blind, comparative study of oral metronidazole and tinidazole in treatment of bacterial vaginosis. Indian J Pharmacol. 2016; 48: 654-658.

[42] Svensson M, Ström M, Nilsson M, al. Pharmacodynamic effects of nitroimidazoles alone and in combination with clarithromycin on Helicobacter pylori. Antimicrob Agents Chemother. 2002; 46 : 2244-2248.

[43] Hu Y, Wan JH, Li XY, et al. Systematic review with meta-analysis: the global recurrence rate of Helicobacter pylori. Aliment Pharmacol Ther. 2017; 46: 773-779.

[44] Malfertheiner P, Bazzoli F, Delchier JC. Helicobacter pylori eradication with a capsule containing bismuth subcitrate potassium, metronidazole, and tetracycline given with omeprazole versus clarithromycin-based triole therapy: a randomised, open-label, non-inferiority, phase 3 trial. Lancet 2011; 377: 905-913.

[45] Liang X, Xu X, Zheng Q. Efficacy of bismuth-containing quadruple therapies for clarithromycin-, metronidazole-, and fluoroquinolone-resistant Helicobacter pylori infections in a prospective study. Clin Gastroenterol Hepatol. 2013; 11: 802-807.e1.

[46] Hsu PI, Chen WC, Tsay FW. et al. Ten-day quadruple therapy comprising proton-pump inhibitor, bismuth, tetracycline, and levofloxacin achieves a high eradication rate for Helicobacter pylori infection after failure of sequential therapy. Helicobacter 2014; 19: 74-79.

[47] Nyssen OP, McNicholl AG, Gisbert JP. Meta-analysis of three-inone single capsule bismuth-containing quadruple therapy for the eradication of Helicobacter pylori. Helicobacter 2019; 24: el2570.

[48] Savoldi A, Carrara E, Graham Dy, et al. prevalence of antibiotic resistance in Helicobacter pylori: a systematic review and metaanalysis in World Health Organization regions. Gastroenterology 2018 ; 155: 1372-1382.e17.

[49] McNicholl AG, Tepes B, Gasbarrini A, et al. Tul328 Pan-European registry on $H$. pylori management (Hp EuReg): interim analysis of first- and second line-treatments. Gastroenterology 2016; 150(Suppl 1): S875-S876.

[50] Chen MJ, Chen CC, Chen YN, et al. Systematic review with meta-analysis: concomitant therapy vs. triple therapy for the firstline treatment of Helicobacter pylori infection. Am J Gastroenterol. 2018; 113: 1444-1457.

(Patai Árpád dr.,

Szombathely, Markusovszky L. u. 5., 9700 e-mail: pataiarpaddr@gmail.com)

A cikk a Creative Commons Attribution 4.0 International License (https://creativecommons.org/licenses/by/4.0/) feltételei szerint publikált Open Access közlemény, melynek szellemében a cikk bármilyen médiumban szabadon felhasználható, megosztható és újraközölhető, feltéve, hogy az eredeti szerző és a közlés helye, illetve a CC License linkje és az esetlegesen végrehajtott módosítások feltüntetésre kerülnek. (SID_1) 